\title{
Factors Affecting Effectiveness of E-Procurement in Business Organizations, a Survey of Safaricom Dealers in Nakuru CBD-Kenya
}

\author{
Eunice Waruguru, Sophia Nduta Kiruri \\ Department of Accounting, Finance and Management Science, Egerton University, Nakuru, Kenya \\ Email address: \\ yunnywa@yahoo.com (E. Waruguru), sophiekiruri@yahoo.com (S. N. Kiruri)
}

\section{To cite this article:}

Eunice Waruguru, Sophia Nduta Kiruri. Factors Affecting Effectiveness of E-Procurement in Business Organizations, a Survey of Safaricom Dealers in Nakuru CBD-Kenya. International Journal of Economics, Finance and Management Sciences. Vol. 3, No. 3, 2015 , pp. $303-310$. doi: $10.11648 /$ j.ijefm.20150303.27

\begin{abstract}
The study focused on establishing factors affecting effectiveness of e-procurement in business organizations. It was carried out among Safaricom dealers in Nakuru Central Business District (CBD). The specific objectives that guided the study were: to find out how e-security affects effectiveness of e-procurement among Safaricom dealers in Nakuru CBD; to determine the extent to which quality of software systems affect the effectiveness of e-procurement among Safaricom dealers in Nakuru CBD; to find out how staff training affects the effectiveness of e-procurement among Safaricom dealers in Nakuru CBD; and to determine how subcontracting affects the effectiveness of e-procurement among Safaricom dealers in Nakuru CBD. The findings of the study will be of great importance to Safaricom dealers as well as other business organizations for they will get to know the factors affecting the effectiveness of e-procurement in their organizations and thereby come up with measures to enhance the effectiveness of e-procurement process as a whole. A survey research design was adopted for the study where 31 procurement personnel working in Safaricom dealer shops in Nakuru CBD formed the target population for the study. A census technique was used where all 31 respondents were included for the study. A questionnaire was used as the data collection instrument and contained closed ended questions. Data analysis was done using descriptive statistics such as frequencies and percentages, while presentation of the results was in the form of tables, charts and graphs which facilitated clear interpretation of results and drawing of conclusion. The findings revealed that e-security affected the effectiveness of e-procurement among Safaricom dealers in Nakuru CBD to a large extent. The quality of software that was being used by Safaricom dealers was found to affect the effectiveness of e-procurement to a large extent. Training sessions were offered to employees of Safaricom dealers often and the level at which training was found to affect the effectiveness of e-procurement was to a large extent. Also established was that subcontracting affected the effectiveness of e-procurement to a very large extent. Based on these findings, the researcher recommended that regular software updates should be done and firewalls installed as e-security measures to forbid outside threats such as hackers and viruses from gaining access to the system and thereby safeguarding data being transacted. The researcher suggested that further research should be conducted to determine the challenges faced in the implementation of information technology in the procurement process.
\end{abstract}

Keywords: E-Procurement, Business Organizations, Nakuru CBD

\section{Introduction}

\subsection{Background of the Study}

E-procurement is the business to business or business to consumer or business to government purchase and sale of supplies, work and services through the internet as well as other information and networking systems such as electronic data interchange (EDI). The study purposed to find out the factors affecting effectiveness of using computers or electronic data interchange in business organizations as far as the procurement procedures are concerned (Lysons and Farrington, 2006).

The use of inter-organizational systems such as electronic data interchange and internet-based extranets enable new types of collaborative alliances between separate trading partners (Philips, 2003). Most organizations in Kenya today are adopting e-procurement as a way of operating their 
activities and getting feedback by use of emails, extranets and other internet technologies used to support every business (Mentzer, 2006).

E-procurement enables users within organizations to order directly from an electronic catalogue without interference from a purchasing department. Orders are acknowledged automatically by the supplier and there is no need to contact the purchasing department with questions such as when the order will be delivered and also what terms and conditions apply since the user can verify the order status online when desired (O’Brien, 2004).

Many suppliers nowadays offer detailed tracking and tracing facilities which enable their customers to monitor orders, follow ups and delivery real time. Besides this, procurement systems enable electronic invoicing and invoice matching. As a result, the traditional purchasing cycle is reduced and simplified considerably.

Safaricom Limited is one of the blue chip companies in Kenya. It is the leading mobile network operator that was formed in 1997 as a fully owned subsidiary of Telkom Kenya. In May 2000, Vodafone group of the United Kingdom acquired $40 \%$ stake and management of the company. It has directly employed over 1500 staff mainly stationed in Nairobi and other major towns in Kenya such as Mombasa, Kisumu, Nakuru, Eldoret, Kakamega, and Nyeri among others. Currently, it has nationwide dealers to ensure that customers across the country have access to its products and services.

Nakuru town has a significant number of Safaricom dealers both within the Central Business District (CBD) and its suburbs. Due to security reasons, support infrastructure and access to the market, most large operators are located in the CBD. E-procurement is in the increase in Kenya following the technological advancements that the country has witnessed and Nakuru town currently has access to speedy internet services courtesy of the various providers such as Jamii Telkom (JTL), Kenya Data Networks (KDN), Access Kenya, and Telkom Kenya, among others. This has not only increased the internet connectivity, but also the cost and usage amongst its residents and e-commerce is the new frontier in the field of business.

\subsection{Statement of the Problem}

For the past years since the introduction of computers, the objective of procurement has not been attained. Even though Safaricom Limited is among the first organizations to introduce computers in their business activities, procurement process is still facing challenges and more so it is still done manually in many organizations. This is mainly because many organizations lack the funds to install software systems that are right for their business activities and also the lack of knowledge and skills on how to operate these systems. In the long run, such organizations consider it more expensive in that they would still be required to train their staff on how to use the software and still rely on the software provider for support. This would necessitate the creation of an IT department which firms find easier to avoid through manual procurement process. In some cases, the firms have to train their suppliers and other business partners on how to use their system in order to enhance smooth running of the procurement process. It is in this regard that the researcher set out to find the factors affecting the effectiveness of e-procurement in business organizations specifically among Safaricom dealers in Nakuru CBD since it is a mandatory to conduct business electronically.

\subsection{Objectives of the Study}

The main objective of the study was to explore factors affecting effectiveness of e-procurement in business organizations. Hence, the specific objectives of the study were:

i. To find out how e-security affects effectiveness of e-procurement among Safaricom dealers in Nakuru CBD.

ii. To determine the extent to which quality of software systems affect the effectiveness of e-procurement among Safaricom dealers in Nakuru CBD.

iii. To find out how staff training affects the effectiveness of e-procurement among Safaricom dealers in Nakuru CBD.

iv. To determine the extent to which subcontracting affects the effectiveness of e-procurement among Safaricom dealers in Nakuru CBD.

\section{Literature Review}

\subsection{Theoretical Literature}

E-procurement is the framework for inter-organizational collaboration. It denotes the seamless application of information and communication technology from its point of origin to its end along the entire value change of business process conducted electronically and designed to enable the accomplishment of a business goal.

E-procurement is of course only a special application of the general benefits that computerization may bring to any function in an organization. This include the ability to store and retrieve a great quantity of data, process such data rapidly with a high degree of accuracy, eliminate much routine error and use exception techniques which save time by notifying these variations which require management action. Reduction of routine clerical activity by automatic preparation of documents such as purchase requisitions, orders, acknowledgement forms, progress letters and formalizing of streamlined procedures that might not otherwise be contemplated (Ibid).

In Safaricom, procurement is a complete function rich in its purchasing system which interferes seamlessly with the requisition system. Dealers make there requisition orders through the same platform known as dealer portal. Every organization has its unique code of login in and doing business with Safaricom. For this to happen, Safaricom relies on electronic data interchange in its operations where data is shared between the bank, Safaricom and the dealers (Atieno, 2013). 
All dealers bank to one consolidated holding account but indicate their specific banking code which uniquely identifies them. Once the banking is done, the finance department synchronizes their bank data and confirms the banking; the amount banked is credited to the dealer portal. The dealer logs in and places the order through the system to Safaricom logistics, indicating the preferred point of collection, upon approval, dealer gets a reference number through soft copy and the same is printed as a hard copy at the point of collection indicated. The authorized dealer staff then collects the specified stock and gets a copy of the order and a delivery note of the same. However, this only happens with some products. For bulk products, the portal does not allow the dealer to indicate point of collection but by default picks the designated courier service through which the product is dispatched (Ibid).

The use of e-procurement software may make it possible to automate these processes. Companies participating expect to be able to control parts of inventories more effectively, reduce purchasing overheads and improve the cycles. At the same time, ongoing purchases may qualify customers for volume discounts or special offers (Atieno, 2013).

\subsubsection{E-security in E-procurement}

E-security may be used to refer to protecting the system from viruses, attacks by intruders and protection of data being transacted. Information is an asset which like other important business assets has value to an organization and consequently needs to be suitably protected. E-security in procurement has various benefits. It increases privacy and confidentiality as it ensures the protection of sensitive information from unauthorized disclosure. E-security safeguards the accuracy and completeness of information/data given thus ensuring an organization maintains its integrity. It also ensures that information and associated services are available to users when required and that no party can deny the involvement in a transaction (Lysons and Farrington, 2006).

The increasing dependence on systems and technologies for business critical processes is making organizations vulnerable. This is enhanced by the trend of using systems and technologies that are outside an organization IT departments' immediate control. More and more systems are being hosted and managed by third parties that is, Application Service Provision (ASP) and delivered to end users using the internet infrastructure (Ibid).

\subsubsection{Quality of Software Systems in E-procurement}

Quality can be a confusing concept partly because people view quality in relation to different criteria based on their individual roles in the production-marketing value chain. Sunil and Peter (2007) argues that delivery of the service to the internal quality is achieved by embedding throughout the organization a fundamental approach that serves as a basis for assuming quality from design to customer with this in mind everybody in the organization sees that whatever he does has to satisfy the customer.

Hartman (2000) argues that quality is defined as perceived and concerns should dominate the providers' decision making. Consumers may focus on the specification quality of a product or service, or how it compares to competitors in the market place. Products might measure the conformance quality or degree to which the product/service was produced correctly. Support personnel may measure quality in the degree that a product is reliable, maintainable or sustainable. Many people have defined quality from different perspectives.

\subsubsection{Training Organizational Employees}

People are the most important and expensive part of an organization. Organizations' time management for task completion and overall system quality are significantly influenced by the effectiveness of the organizations employees are in short supply. Armstrong (2006) quoted that organizations should not shift their total focus from its employees to the customers as it is very tempting. As much as customers retention and loyalty is important to an organization, great attention should equally be given on the side of the employees bearing in mind that its employees who delivers services to customers and thus its them who retains them and build organizational loyalty in them.

Training is the process of enhancing the skills, capability and knowledge of employees is nourished to give the best results in doing a particular work or task. Training process moulds the thinking of employees and leads to quality performance of employees. It is continuous process and never ending in nature. Employees become more efficient and productive if trained well (Ibid).

\subsubsection{Subcontracting in E-procurement}

Subcontracting is the practice of assigning part of the obligations and tasks under a contract to another party known as a subcontractor. Subcontracting is very useful in situations where the range of required capabilities for a project is too diverse $t$ be possessed by a single general contractors. In such cases, subcontracting parts of the project that do not firm the general contractor's core competences may assist in keeping costs under control and mitigate overall project risk (Bailey et al., 1998).

According to Saunders (1997) subcontracting has developed as a reaction to the over diversification that took place in 1970 s and early 1980s. This has led to many organizations to reveal on their core competences. Many organizations have little or no expertise in carrying out many services or even knowledge of market rate cost. Organizations should subcontract these activities to specialize and concentrate its energies on core activities. Subcontracting is the strategic use of outside resources to perform activities initially handled by internal staff. Subcontracting is essentially the transfer of production of goods and services that had been performed internally to an external party.

Specialized subcontractors are better positioned to secure and maintain a grip at the leading edge of technological change and innovation. He is legally responsible to the main contractor. According to Lysons and Farrington (2006) companies can also make customer services more effective by taking advantage of the technological innovations that some providers offer and here there may sometimes be an advantage in off shoring. That is because some foreign subcontracting 
providers have offerings their domestic counterparts can't match in terms of technologies that help guide customer service by recognizing patterns in consumer behavior.

One way to mitigate the damage from subcontracting customer service is to invest the money the company saves to improve the quality of the company's products or services, or to cut prices rather than simply pocket the savings as extra profit. Our findings suggest that this is not happening in most cases. Among the companies we studied that have outsourced customer satisfaction score; their customers didn't feel that they were getting any more for their money than they did before the company started subcontracting (Ibid).

In the case of Safaricom dealers, products pass through several channels from the time of release by the main contractor before reaching the consumers. In the case of airtime, after been manufactured by the main contractor, it is distributed by a subcontractor called Andy distributors to the dealers. The dealers sell the airtime to $t$ in smaller packages who then sell to consumers. Even though the manufacturers and the distributors have specialized in their profession, dealers contact Safaricom directly in case of a problem.

\subsection{Empirical Literature}

Anyango (2005) asserts that companies are re-engineering their supply chain management software for example, the demand of e-procurement are pushing organizations to use their internets, and e-commerce to help them re-engineer their relationship with their suppliers, distributors and retailers to meet their e-commerce customers imperative needs to what they want, where and when it is wanted at the best possible cost. E-procurement has revolutionalized and its effects on purchasing practices have improved in various businesses. The companies offering e-procurement systems have generated a considerable cost saving, productivity and efficiency.

Mathane (2007) on Factors Influencing Adoption of E-procurement in the Supply Chain states that the time taken for the acquisition by use of e-procurement is very important. The system should have the time that is taken to acquire goods or to exchange information through the supply chains. For this is much effective system of managing these chains.

Chepkonga (2010) on Factors Affecting Order Placement in Procurement Process observed that lead time depends on a number of factors, from the time it takes to create the machinery to the speed of delivery system. Lead time can be reduced if information technology is implemented on order placement and also introduction of online shopping.

Anyango (2005) on Factors Affecting Effectiveness of IT on Procurement Function stated that the use of IT in managing procurement function has developed rapidly over the last 10 years. Research demonstrates that IT utilized in a variety of procurement application including the communication with vendors, checking vendor price quotes and making purchases from vendor catalogs. Vendor negotiations have also been streamlined through the use of IT. It is being used in order processing applications. The most frequent areas of application include order placement and order status. Use of
IT in order processing has resulted in increased accuracy levels and increased reliability.

Serem (2005) on Effects of Computerization of Kenya Ports Authority, stated that the successful going live of phase one of the IT strategy was a major milestone in the organization strategic road map and resolve to become an e-port and rated amongst top twenty ports in the world by the year 2000 . The introduction of computers have witnessed and experienced drastic change in their working system. This include less paperwork and decision making has improved due to availability of online and timely information and service delivery to internal and external customers which used to take up to two days, now takes two minutes (Ibid).

Reduced movement of staff, that is, a letter can be edited and e-mailed without sending by post or use of a messenger. Also the internal messaging service has reduced paper flow substantively and eliminated independent connections to external internet service providers which used to cost the authority Kshs. 140,000 per month.

Erasto (2005) on The Role of Vendor Managed Inventories in Customer/Supplier Chain states that the vendor managed inventory process is a combination of e-commerce, software and people. The e-commerce layer is the mechanism through which companies communicate the data. The vector markup language (VML) data can be communicated via electronic data interchange where compatible customer/supplier software and hardware are interlinked or any other reliable communications method. The key feature of the e-commerce layer is that data is timely and accurate.

Chebii (2006) stated that the internet has opened the door to new ways of shopping. Shopping in the internet offers convenience way and time saving benefits to shoppers as compared to traditional way of shopping. This mode of shopping eliminates the agony of traffic jams, pick pockets and bad weather to travel and no transport cost is involved.

Wangare (2005) on Top Performance through E-procurement revealed that, top performers conduct more than $20 \%$ of their procurement online while they use the internet for several e-procurement applications such as communicating with vendors, checking vendor price quotes and purchasing from vendor catalogues. The internet has also enabled companies to set early warning, damage system provide information on warranty agreements and assist in vendor negotiations.

E-procurement functions must guard and mitigate risks, understand the market, build good relationship with the supplier who meet needs in a timely manner and constantly monitor performance to improve service provision. This therefore raises the need for an organization to have clearly defined policies that can be understood (Ibid).

Munene (2006) on Factors Affecting the Use of Electronic Banking Service suggests that the use of computers in banks is growing at a higher rate with inappropriate IT platform, banks growth is held back. This translates into high transactions costs and forces the banks to open more and bigger branches to accommodate the swelling number of customers. In order to accommodate these customers, banks have introduced a 
number of e-banking services aimed at meeting the needs of its customers. E-banking is one of the services which has been introduced and enables world wide access to ones account at the convenience of a customer. E-banking ensures 24 hours access to one's account every day, easy payment solutions and affordable transaction fees.

Wanyama (2012) on Contribution of E-procurement in Enhancing Procurement Process states that, application of IT helps to ensure a continuous production and distribution of goods and services in an organization. It guarantees on timely delivery and this creates a real life environment between buyer and supplier. Due to inadequate skills of employees in computer operation, it is very important to train them for the purpose of good management and organization performance.

\subsection{Conceptual Framework}

The conceptual framework shows the relationship between variables and can be explained as follows: the independent variables are the factors affecting effectiveness of e-procurement in business organizations and include e-security, quality of software, staff training and subcontracting. When the intervening variables are taken care of, so are the factors and hence there is effective e-procurement (dependent variable). On the contrary, when the intervening variables are not dealt with properly, the end result is ineffective e-procurement.

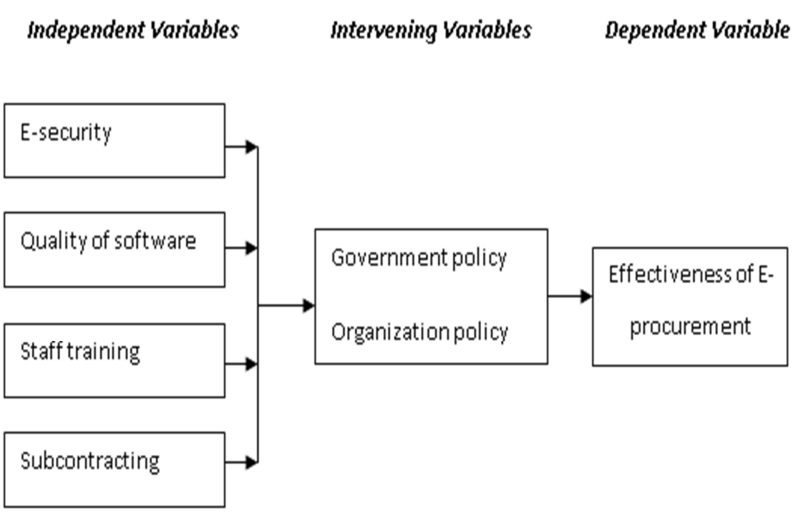

Fig. 1. Conceptual framework.

\section{Research Methodology}

\subsection{Research Design}

A survey research design was adopted for the study. A survey attempts to collect data from members of a population in order to determine the current status of the population with respect to one or more variables (Mugenda and Mugenda, 1999). A survey research design was suitable and appropriate for this study because it allowed collection of large amounts of data from the field. By using survey design there was generalization of information related to the target population.

\subsection{Target Population}

According to Mugenda and Mugenda (2003), target population is a population to which the researcher wants to generalize the results of a study. The study targeted procurement personnel of Safaricom dealer shops in Nakuru CBD. According to the Nakuru County Government Licensing Office (2014), there are 11 Safaricom dealer shops in Nakuru CBD and the researcher selected all of them for study. A total of 31 procurement personnel formed the target population for the study. This population was chosen because of their influence over procurement activities of the The distribution of target population for the study is shown in the subsequent table.

Table 1. Distribution of Target Population.

\begin{tabular}{ll}
\hline Manufacturing Firm & Target Population \\
\hline Com21 Ltd. & 4 \\
Simba Telecom & 3 \\
Wabcom Technologies & 2 \\
Happy Go Ltd. & 3 \\
Strategic Communication & 1 \\
Peace Communication & 3 \\
Flashdial Connections & 3 \\
Samchi Ltd. & 4 \\
Pace Connect & 3 \\
Visage Ltd. & 2 \\
Bonga Connections & 3 \\
Total & 31 \\
\hline
\end{tabular}

Source: Nakuru County Government Licensing Office (2014)

\subsection{Sampling Design and Procedures}

A census technique was used where all 31 procurement personnel of Safaricom dealer shops in Nakuru CBD were included in the study. This was because they had the required information with respect to the objectives of the study. Census technique was used because the population was considerably small and manageable.

\subsection{Data Collection Instruments and Procedures}

A questionnaire was used as the data collection instrument for the study and was developed through the guidance of the study's objectives and research questions. It was found to be an appropriate instrument as it was easier for the researcher to collect data from the respondents. Furthermore, it was viewed as the most appropriate as it permits greater depth of response from the respondents' thus more detailed data about the views of the respondents on the subject could be obtained. The questionnaire contained closed ended questions and were administered on a drop and pick up later basis where the respondents were given 3 days to go through the questions at their own pace. This was done in order to ensure uniformity of answers and also to increase the response rate.

The validity of the research instrument was achieved through the expert judgment of the research supervisor. The reliability of the instrument was ascertained by conducting a pilot study at Gilgil town where 4 questionnaires were randomly distributed to procurement personnel of 2 Safaricom dealer shops (Interservices Ltd. and Fon Xpress). Since the instrument was found to yield stable and desirable results which could be relied upon, it was adopted for the study. 


\subsection{Data Analysis and Presentation}

After the questionnaires were collected, before analysis was done, all questionnaires were adequately checked for verification. They were edited to correct any errors, coded for consistency and completeness. Data analysis was done using descriptive statistics where frequencies and percentages were used. Presentation of the results was done in form of tables, charts and graphs which facilitated clear interpretation of results and assisted in drawing of conclusions.

\section{Research Findings}

\subsection{Correlation Analysis}

A correlational analysis was conducted to determine the relationship between E-security, quality of software, staff training and ub-contracting and effectiveness of E-procurement,. The results were as presented in table 2.

Table 2. Results of Correlational Analysis.

\begin{tabular}{|c|c|c|c|c|c|c|}
\hline & & E-security & Quality of software & Staff training & Subcontracting & Effectiveness of E-procurement \\
\hline \multirow[t]{3}{*}{ E-security } & Pearson Correlation & 1 & .038 & .128 & .094 & .048 \\
\hline & Sig. (1-tailed) & & .397 & .188 & .284 & .372 \\
\hline & $\mathrm{N}$ & 31 & 31 & 31 & 31 & 31 \\
\hline \multirow{3}{*}{$\begin{array}{l}\text { Quality of } \\
\text { software }\end{array}$} & Pearson Correlation & .038 & 1 & .232 & .225 & .082 \\
\hline & Sig. (1-tailed) & .397 & & .053 & .084 & .285 \\
\hline & $\mathrm{N}$ & 31 & 31 & 31 & 31 & 31 \\
\hline \multirow[t]{3}{*}{ Staff training } & Pearson Correlation & .128 & .232 & 1 & .225 & .041 \\
\hline & Sig. (1-tailed) & .188 & .053 & & .084 & .387 \\
\hline & $\mathrm{N}$ & 31 & 31 & 31 & 31 & 31 \\
\hline \multirow[t]{3}{*}{ Subcontracting } & Pearson Correlation & .094 & .225 & 1 & 1 & .116 \\
\hline & Sig. (1-tailed) & .284 & .084 & & & .240 \\
\hline & $\mathrm{N}$ & 31 & 31 & 31 & 31 & 31 \\
\hline \multirow{3}{*}{$\begin{array}{l}\text { Effectiveness of } \\
\text { E-procurement }\end{array}$} & Pearson Correlation & .048 & .082 & .041 & .116 & 1 \\
\hline & Sig. (1-tailed) & .372 & .285 & .387 & .240 & \\
\hline & $\mathrm{N}$ & 31 & 31 & 31 & 31 & 31 \\
\hline
\end{tabular}

From table 2, the Pearson Correlation $=.048$ indicates a weak positive correlation which implies that E-security positively affects effectiveness of E-procurement. The significance value of $0.372(>0.05)$ however indicates that the relationship is not statistically significant. The Pearson Correlation $=.082$ indicates a weak positive correlation which implies that quality of software has weak positive effect effectiveness of E-procurement. The significance value of $0.285(>0.05)$ however indicates that the relationship is not statistically significant.

The Pearson Correlation $=.041$ indicates a weak positive correlation which implies that staff training positively affect effectiveness of E-procurement. The significance value of
$0.387(>0.05)$ however indicates that the relationship is not statistically significant. Similarly, the Pearson Correlation value of 0.048 indicates positive relationship that implies that subcontracting positively affects effectiveness of E-procurement. The significance value of $0.372(>0.05)$ indicates that the relationship is not statistically significant.

\subsection{Regression Analysis}

To determine the overall effect of E-security,

Quality of software, staff training and sub-contracting on effectiveness of E-procurement, a multiple regression analysis was conducted. The results were as presented in tables 3 .

Table 3. Regression Analysis.

\begin{tabular}{lllll}
\hline Model & R & R Square & Adjusted R Square & Std. Error of the Estimate \\
\hline 1 & $.095 \mathrm{a}$ & .090 & -.056 & .837 \\
\hline
\end{tabular}

a. Predictors: (Constant), E-security, quality of software, staff training and sub-contracting

From table 3, the R square reveals that E-security, quality of software, staff training and sub-contracting collectively affect effectiveness of E-procurement up to $9 \%$. This is the collective effect of the three variables on effectiveness of E-procurement

Table 4. Table of Coefficients.

\begin{tabular}{|c|c|c|c|c|c|c|}
\hline \multirow{2}{*}{ Model } & & \multicolumn{2}{|c|}{ Unstandardized Coefficients } & \multirow{2}{*}{$\begin{array}{l}\text { Standardized Coefficients } \\
\text { Beta }\end{array}$} & \multirow{2}{*}{$\mathbf{T}$} & \multirow{2}{*}{ Sig. } \\
\hline & & B & Std. Error & & & \\
\hline \multirow{5}{*}{1} & (Constant) & 3.163 & .919 & & 3.442 & .001 \\
\hline & E-Security & .047 & .163 & .042 & .285 & .777 \\
\hline & Quality of Software & .097 & .192 & .076 & .507 & .615 \\
\hline & Staff Training & .023 & .186 & .018 & .121 & .904 \\
\hline & Subcontracting & .025 & .243 & .017 & .103 & .919 \\
\hline
\end{tabular}

a. Dependent Variable: Effectiveness of E-Procurement 
Table 4 presents the coefficients of the independent variables; E-security, quality of software, staff training and subcontracting. From the table the regression model of the study can be generated as:

$$
\mathrm{Y}=3.163+0.047 \mathrm{X}_{1}+0.097 \mathrm{X}_{2}+0.023 \mathrm{X}_{3}+0.025 \mathrm{X}_{4}
$$

Where; Y - Effectiveness of E-Procurement

$\mathrm{X}_{1}-$ E-Security

$\mathrm{X}_{2}$ - Quality of Software

$\mathrm{X}_{2}-$ Staff Training

$\mathrm{X}_{4}$ - Subcontracting

\section{Conclusions and Recommendations}

From the findings of the study, it can be concluded that e-security affects the effectiveness of e-procurement among Safaricom dealers in Nakuru CBD to a large extent hence making it a necessity for the dealers to make effective transactions. Lack of e-security was found to hinder the effectiveness of e-procurement.

Quality of software used by Safaricom dealers was found to affect the effectiveness of e-procurement to a large extent. The use of high quality software was found to reduce errors to minimal thereby enhancing the effectiveness of e-procurement.

Safaricom dealers offered training sessions for their workforce on a regular basis. Staff training was found to affect the effectiveness of e-procurement to a large extent whereby it helped in improving the understanding and coordination level of the employees. It also helped in reducing errors and increasing the number of transactions thus enhancing the effectiveness of e-procurement.

Subcontracting affected the effectiveness of e-procurement to a very large extent and Safaricom dealers were basically content with the services offered by subcontractors. Through subcontracting, there was reduction of time taken in service delivery thereby enhancing the effectiveness of e-procurement.

Since e-security was found to affect the effectiveness of e-procurement among Safaricom dealers, it is important that regular software updates are done and firewalls installed to forbid outside threats such as hackers and viruses from gaining access to the system and thereby safeguarding data being transacted. This should go a long way in creating a sense of confidence amongst users including suppliers who will be assured of security when transacting online and thereby enhance the effectiveness of e-procurement.

Safaricom dealers should invest in high quality software so as to reap the best benefits and enhance the effectiveness of e-procurement. They should ensure that their software systems are updated on a regular basis to avoid them becoming obsolete. In order to realize optimum performance and effectiveness of e-procurement among Safaricom dealers, more regular training sessions should be arranged for employees so as to keep them abreast with the changing trends or updates of the system. This will give them a better understanding of e-procurement and thereby enhance their efficiency levels. Subcontracting of services should be highly encouraged amongst Safaricom dealers in Nakuru CBD since professionals were highly involved and were therefore more dedicated towards achieving certain objectives. By subcontracting services, the dealers were assured of quality service delivery and therefore high effectiveness levels in e-procurement.

Further research should be conducted to determine the challenges faced in the implementation of information technology in the procurement process. Since the current study was confined to Safaricom dealers in Nakuru CBD, the researcher suggests that similar research should be carried out in a wider geographical region and with a larger sample size to determine whether similar results can be achieved for more prudent generalization of the findings

\section{References}

[1] Algava, E. and Amira, S. (2011). Impact of Subcontracting on Working Conditions. New Delhi: Sultan Chand \& Bros.

[2] Anyango, P. (2005). Factors Affecting Effectiveness of IT on Procurement Function, Unpublished Research Project, Kenya Institute of Management, Nakuru.

[3] Atieno, J. (2013). An Evaluation of Challenges Faced by Safaricom Dealers in Enhancing Profitability, Unpublished Research Project, Kenya Institute of Management, Nakuru.

[4] Armstrong, M. C. (2006). Human Resource Management Practice, (9th Edition). London: Kogan Page.

[5] Bailey, P., Farmer, D., Jessop, D. and Jones, D. (1998). Purchasing Principles and Management, (8th Edition). London: Prentice Hall Publishing Company.

[6] Chebii, J. (2006). Effects of Computerization on Organization Performance. Unpublished Research Project, Kenya Institute of Management, Nakuru.

[7] Chepkonga, C. (2010). Factors Affecting Order Placement in Procurement Process, Unpublished Research Project, Kenya Institute of Management, Nakuru.

[8] Cole, G. A. (2002). Personnel and Human Resource Management, (5th Edition). London: Book Power ELST Imprint.

[9] Crosby, P. B. (1979). Conformance to Requirements, Quality is Free. New York: McGraw Hill.

[10] Dwyer, J. (2001). E-commerce Growth Prospects Remain Strong. London: Financial Times.

[11] Erasto,W. (2005). The Role of Vendor Managed Inventories in Customer/Supplier Chain, Unpublished Research Project, Kenya Institute of Management, Nakuru.

[12] Gilbert, A. (2000). E-Procurement for Smaller Users. London: Financial Week

[13] Graham, H. T. and Bennett, R. (1998). Human Resource Management, (9th Edition). London: Guildhall University. 
[14] Hartmann, G. (2000): Pleasures and Pitfalls of E-procurement: Lodging Hospitality.

[15] Hassan, M. (2014). Effects of E-procurement on Sustainability of Competitive Advantage in Supermarkets. Unpublished Research Project, Kenya Institute of Management, Nakuru.

[16] Kumar, R. and Connie, C. (1999). Educating Senior Management on the Strategic Benefits of Electronic Data Interchange, Journal of Systems Management.

[17] Leenders, F. and Fearon, J. (2002). Purchasing and Supply Management. (10th Edition). New York: McGraw Hill.

[18] Lysons, K. and Farrington, B. (2006). Purchasing and Supply Chain Management, (7th Edition). Tata: McGraw Hill Publishing Company.

[19] Mathane, R. (2007). Factors Influencing Adoption of E-procurement in the Supply Chain, Unpublished Research Project, Kenya Institute of Management, Nakuru.

[20] Mentzer, J. T. (2006). Supply Chain Management, (5th Edition). New Delhi: Sage Publications Inc.

[21] Mugenda, O. M. and Mugenda, A. G. (2003). Research Methods: Quantitative and Qualitative Approaches (Revised). Nairobi: ACTS Press.

[22] Mugenda O. M. and Mugenda A. G. (1999). Research Models: Quantitative and Qualitative Approaches. Nairobi: Acts Press.

[23] Mullins, J. (2002). Management and Organizational Behavior, (4th Edition). London: Prentice Hall.

[24] Munene, Z. (2006). Factors Affecting the Use of Electronic Banking Service, Unpublished Research Project, Kenya Institute of Management, Nakuru.
[25] O'Brien, L. Ghodspour, F. (1998). Supplier Selection and Evaluation Method. New Jersey: ELST Publishers

[26] Robbins, S. P. and Judge, T. (2007). Essentials of Organizational Behavior, (9th Edition). New York: AMACOM.

[27] Saunders, M. (1997). Strategic Purchasing and Supply Chain Management, (2nd Edition). New York: Prentice Hall.

[28] Serem, T. (2005). Effects of Computerization of Kenya Ports Authority, Unpublished Research Project, Kenya Institute of Management, Nakuru.

[29] Steve, E. (2007). Effective Training Techniques through Employee Involvement. Pittsburgh: P. A. \& Sons.

[30] Sunil, C. and Peter, M. (2007). Supply Chain Management. (3rd Edition). New Delhi: Asoke K. Ghosh.

[31] Thai, K. V. (2004). Introduction to Public Procurement (5th Edition). Florida: Atlantic University.

[32] Wang, W., and Chang, P. P. (2008). Entrepreneurship And Strategy In China: Why Porter's Five Forces May Not Be. Journal of Chinese Entrepreneurship, Vol. 1 Issue No. 1 pp. 53-64.

[33] Wangare, R. (2005). Top Performance Through E-procurement, Unpublished Research Project, Kabianga University, Kericho.

[34] Wanyama, W. (2012). Contribution of E-procurement in Enhancing Procurement Process, Unpublished Research Project, Kenya Institute of Management, Nakuru.

[35] Warren, D. (2003). Supplies and Organization Transactions (9th Edition). London: Prentice Hall. 